\title{
An Engineer grapples with sustainable manufacturing
}

\author{
Vijay Srinivasan
}

Published online: 16 February 2011

(C) Springer-Verlag (outside the USA) 2011

It was not that long ago when being "green" was considered mainly a political or a social belief, at least in the USA. It was not in the main stream consciousness of corporate leaders. And how things have changed in the last few years! It is difficult to read a popular magazine or watch commercial television today without being reminded how a particular company is offering an environment friendly product or how it is producing such an offering using responsible, sustainable processes. Serious business publications are full of advice to corporate managers on how to deal with sustainability (now the accepted business and technical term) in the boardroom all the way down to the shop floor. Engineering and technical literature that deal with sustainability issues have seen an explosive growth. Technical conferences held by major engineering societies have several sessions devoted to sustainability, or are even organized around the main theme of sustainability.

\section{How did we get here in just a few years?}

As a research engineer and manager, first in the private sector and now in government service, I have personally witnessed the emergence of a compelling case for sustainable manufacturing and also gained several important insights along the way. From my vantage point, there were

Disclaimer: Mention of commercial products or services in this article does not imply approval or endorsement by NIST, nor does it imply that such products or services are necessarily the best available for the purpose.

V. Srinivasan $(\bowtie)$

National Institute of Standards and Technology, Gaithersburg, MD 20899, USA

e-mail: vsrini@nist.gov three distinct epochs for this emergence characterized by: (1) the initial shock when the European regulation commonly known as Restriction on the use of Hazardous Substances (RoHS) hit the global electronics industry, (2) the epiphany when some smart businesses recognized that there is money to be made in embracing sustainability, and (3) the current awakening that sustainability is the key driver of innovation and is an emerging megatrend in industry.

\section{The initial shock: RoHS hits electronics industry}

On 23 January 2003 the European Union published the directive 2002/95/EC, which quickly became known as RoHS, on the restriction of the use of certain hazardous substances in electrical and electronic equipment. It went into effect on 1 July 2006. From that date, it restricted the use of lead, mercury, cadmium, hexavalent chromium, and two polybrominated compounds (biphenyls, diphenyl ether) in all consumer and most commercial equipment sold in the European Union. Its impact on the global electronics industry was electric, so to speak, because a quick substitute for lead had to be found for soldering. I was working for a company that did a lot of electronics manufacturing, among other things, at that time and so the experience was personal. The industry did find a substitute in tin, with some accompanying issues of its own, but at considerable cost and anguish. And it learned some important lessons.

Even though the European regulation was local, in the sense that it affected only those products that are sold in that part of Europe governed by the European Union directives, its impact was global because no electrical or electronics manufacturer anywhere in the world was willing to be locked out of the lucrative European market. 
Once again, it reminded business leaders that local environmental regulations motivated by local political pressures have global impact, because while all politics may be local (in the immortal words of the late US Speaker of the House, Tip O'Neal) business today is global. Decades earlier, the automotive industry learned a similar lesson when the state of California mandated higher fuel efficiency in cars sold in that state, which effectively drove manufacturers to apply that standard to all of their cars.

The RoHS sounded a wake-up call to the manufacturing industry in which I was employed. It was the beginning of a long stream of regulations that restrict the materials used in products and their manufacturing processes. Business leaders soon realized that reacting to every new regulation will be costly and impractical in the long run. What they needed was a proactive business agenda to address the social and political pressures on environmental issues. In the corporate boardrooms, this recognition propelled sustainability as a lead item in any discussion on corporate social responsibility (CSR). In the meantime, there was also a realization that money can be made while pursuing sustainability.

\section{The epiphany: there is money to be made}

Business depends on profits, without which it will not exist. Initial industrial efforts toward sustainable manufacturing focused on lean manufacturing practices, which reduced waste and hence the cost of manufacturing. This immediately contributed to the bottom-line savings even without the benefit of any top-line growth. This also proved to be the main source of showing at least some profits during the global economic slowdown. It is equivalent to plucking the "low hanging green fruits." In fact, in tough economic times, lean manufacturing practices offer the first line of attack available to business executives to contain costs, with the added beneficial side effect on sustainability due to the reduction of waste.

But the top line growth cannot be ignored. It is here that I witnessed the emergence of sustainability as a business strategy, especially as a brand. Jeffrey Immelt of the General Electric Company observed that "green is green", the latter meaning green dollars, and launched ecomagination as a corporate practice and as a company brand image in media advertisements. Walmart insisted on its suppliers to adopt sustainable practices, thus enhancing its brand image. IBM, Nokia, Pitney Bowes, and Sony created Eco-patents Commons to freely share patents that contribute to development of sustainable products and sustainable manufacturing practices-and made sure that this news got wide publicity.

In addition to positioning sustainability as a business brand strategy to drive top-line revenue growth, new business opportunities for green products have emerged. Energy efficient equipment and machines, controllers for energy and emission management, and solar and wind power generators are selling well. Along with them, the need for smart energy grid infrastructure has received proper recognition and necessary attention. It was at this juncture I made the transition from the private sector to government service at the US National Institute of Standards and Technology (NIST).

\section{The awakening: sustainability is a key driver of innovation}

Amidst the flurry of tactical business reaction to regulations and opportunistic brand burnishing, there was an awakening that what we are witnessing is the beginning of a new business era that will last for quite a while. In an influential Harvard Business Review (HBR) article in September of 2009, the late Prof. C.K. Prahalad and his colleagues posited that sustainability is the new key driver of innovation and proceeded to explain why this is so. They started with the observation that being environment-friendly can lower the cost and increase the revenue. Then they proceeded to predict that, in the future, only companies that make sustainability a goal will achieve competitive advantage. This is a serious conclusion, because this would mean rethinking business models as well as products, technologies, and processes.

Around the same time the HBR article appeared, the MIT Sloan Management Review published a special report on the business of sustainability. Based on an extensive business survey, it concluded that there is a strong consensus that sustainability is having - and will continue to have-a material impact on how companies think and act. In particular, what principally emerged from this MIT report is that sustainability is not a topic du jour. It is more strategic than what most of us believed initially when RoHS hit the electronics industry.

In a widely attended workshop on sustainable manufacturing held at NIST in the Fall of 2009, many industrial participants echoed this sentiment. They drew a comparison between today's sustainability movement with the total quality management (TQM) whose emergence they witnessed in the US about 30 years ago. Such a comparison is prescient because, as another HBR article in the May, 2010 issue pointed out, a road-map for sustainability may well be provided by our experience with TQM. As I grapple with sustainable manufacturing issues at NIST today, this is one of the most helpful insights because our research strategies for measurements, standards, and technology for sustainability can now learn from what NIST had successfully adopted earlier to support the US national quality 
movement. It would not surprise me at all if you were to find the analogy between sustainable manufacturing and TQM very useful in your realm of responsibilities as well.

\section{Author Biography}

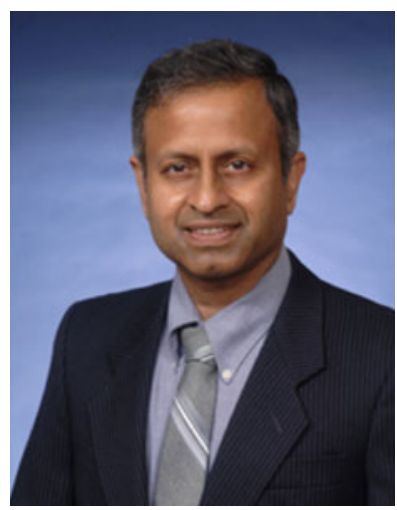

Vijay Srinivasan joined the US National Institute of Standards and Technology at Gaithersburg, Maryland in August, 2009 as the Division Chief of the Manufacturing Systems Integration Division. He comes to NIST from IBM, where he was most recently the Chief Standards and Solutions Officer for Product Lifecycle Management (PLM). Before that, he was a research manager in IBM's T.J. Watson Research Center leading research in the areas of geometric modeling, CAD/CAM, robotics, standards for geometric dimensioning and tolerancing, and data exchange. Dr. Srinivasan also served as an adjunct professor of mechanical engineering at Columbia University, where he has taught geometric modeling and computations and integrated product development. He has published widely, and his book, "Theory of Dimensioning: An introduction to parameterizing geometric models" was published by Marcel-Dekker in 2004. He recently co-authored a book in 2008 on "SOA Approach to Enterprise Integration for Product Lifecycle Management." 